\title{
$\gamma$-Tocotrienol prevents oxidative stress-induced telomere shortening in human fibroblasts derived from different aged individuals
}

\author{
Suzana Makpol,'** Azrina Zainal Abidin,' Khalilah Sairin,' Musalmah Mazlan,' Gapor Md. Top² and Wan Zurinah Wan Ngah' \\ 'Department of Biochemistry; Faculty of Medicine; National University of Malaysia; Kuala Lumpur, Malaysia; ${ }^{2}$ Department of Chemistry; Malaysian Palm Oil Board; \\ Bangi, Selangor Malaysia
}

Key words: $\gamma$-tocotrienol, telomere, telomerase, fibroblasts, oxidative stress, aging

\begin{abstract}
Abbreviations: ALT, alternative lengthening of telomeres; CCM, complete culture media; $\mathrm{CO}_{2}$, carbon dioxide; DNA, deoxyribonucleic acid; DIG, digoxigenin; EMEM, eagle's minimun essential medium; FCS, fetal calf serum; GTT, $\gamma$-tocotrienol; $\mathrm{HDF}$, human diploid fibroblast; $\mathrm{H}_{2} \mathrm{O}_{2}$, hydrogen peroxide; $\mathrm{IC}_{50}$, inhibitory concentration; IMDM, iscove's modified dulbecco's

medium; MF, fibroblasts derived from middle age human; MTS, 3-(4,5-dimethylthiazol-2-yl)-5-carboxymethoxyphenyl

2-(4-sulfophenyl)-2H-tetrazolium; OF, fibroblasts derived from old age human; PCR, polymerase chain reaction; PMS, phenazine methosulphate; ROS, reactive oxygen species; SIPS, stress-induced premature senescence; TRAP, telomeric repeat amplification protocol; TRF, terminal restriction fragment; UV, ultra violet; YF, fibroblasts derived from young human
\end{abstract}

\begin{abstract}
The effects of palm $\gamma$-tocotrienol (GGT) on oxidative stress-induced cellular ageing was investigated in normal human skin fibroblast cell lines derived from different age groups; young (2l-year-old, YF), middle (40-year-old, MF) and old (68-year-old, OF). Fibroblast cells were treated with $\gamma$-tocotrienol for 24 hours before or after incubation with IC dose of $\mathrm{H}_{2} \mathrm{O}_{2}$ for 2 hours. Changes in cell viability, telomere length and telomerase activity were assessed using the MTS assay (Promega, USA), Southern blot analysis and telomere repeat amplification protocol respectively. Results showed that treatment with different concentrations of $\gamma$-tocotrienol increased fibroblasts viability with optimum dose of $80 \mu M$ for $\mathrm{YF}$ and $40 \mu \mathrm{M}$ for both MF and OF. At higher concentrations, $\gamma$-tocotrienol treatment caused marked decrease in cell viability with $I_{50}$ value of $200 \mu M$ (YF), $300 \mu M(M F)$ and $100 \mu M$ (OF). Exposure to $\mathrm{H}_{2} \mathrm{O}_{2}$ decreased cell viability in dose dependent manner, shortened telomere length and reduced telomerase activity in all age groups. The $I_{50}$ of $\mathrm{H}_{2} \mathrm{O}_{2}$ was found to be; YF $(700 \mu \mathrm{M})$, MF $(400 \mu \mathrm{M})$ and OF $(100 \mu \mathrm{M})$. Results showed that viability increased significantly $(\mathrm{p}<0.05)$ when cells were treated with $80 \mu \mathrm{M}$ and $40 \mu \mathrm{M} \gamma$-tocotrienol prior or after $\mathrm{H}_{2} \mathrm{O}_{2}$-induced oxidative stress in all age groups. In YF and OF, pretreatment with $\gamma$-tocotrienol prevented shortening of telomere length and reduction in telomerase activity. In MF, telomerase activity increased while no changes in telomere length was observed. However, post-treatment of $\gamma$-tocotrienol did not exert any significant effects on telomere length and telomerase activity. Thus, these data suggest that $\gamma$-tocotrienol protects against oxidative stress-induced cellular ageing by modulating the telomere length possibly via telomerase.
\end{abstract}

\section{Introduction}

Normal human cells exhibit a limited capacity for proliferation in culture and this finite replicative lifespan has frequently been used as a model of human aging in mitotic tissues and organs. ${ }^{1}$ This phenomenon is considered to be associated with reduction in telomere length as an indicator of the number of cell divisions undergone. The human telomere is a simple repeating sequence of six bases, TTAGGG, located at the ends of chromosomes. ${ }^{2}$ It is thought that telomeres have multiple roles, including protection against degeneration, reconstruction, fusion and loss. ${ }^{3,4}$ The telomeric repeat sequences are added on by the enzyme telomerase which, when present, compensates for the loss of DNA from the end of chromosomes due to incomplete replication. In normal human somatic cells, because of inherent limitations in the mechanics of DNA replication, telomeres shorten at each cell division. In the absence of telomerase, when telomere shortening reaches a critical limit, cells are susceptible to chromosomal aberrations such as end-to-end fusion and aneuploidy. In such a situation, the cells cease to divide and reach replicative senescence. ${ }^{5,6}$ Telomere length may restrict the replicative potential of hemopoietic cells contributing to the decline in immune function with age. ${ }^{7}$ The erosion of chromosome ends, or telomeres, was proposed as a major mechanism that contributes to cellular aging. ${ }^{8}$

While convincing evidence has been obtained that telomere shortening occurs during aging both in vitro and in vivo, 


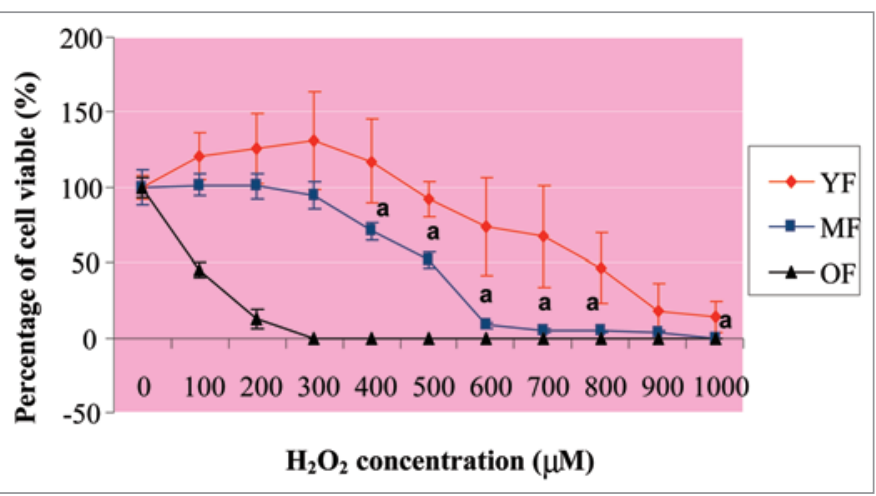

Figure I. Effects of $\mathrm{H}_{2} \mathrm{O}_{2}$ toxicity towards viability of fibroblast cell lines derived from young (YF), middle (MF) and old (OF) age humans as assessed by MTS assay. Fibroblast cells were exposed to increasing concentration $s$ of $\mathrm{H}_{2} \mathrm{O}_{2}$ for 2 hours at $37^{\circ} \mathrm{C}$. No significant difference in viable cell number between control and $\mathrm{H}_{2} \mathrm{O}_{2}$-exposed cultures were observed when the concentration of $\mathrm{H}_{2} \mathrm{O}_{2}$ was less than $500 \mu \mathrm{M}$, $300 \mu \mathrm{M}$ and $20 \mu \mathrm{M}$ for fibroblast cells derived from young, middle and old age humans respectively. Cell viability decreased by $50 \%$ when exposed to $700 \mu \mathrm{M}, 400 \mu \mathrm{M}$ and $100 \mu \mathrm{M}$ of $\mathrm{H}_{2} \mathrm{O}_{2}$ for fibroblast cells derived from young, middle and old age humans respectively. At more than $\mathrm{I}, 000 \mu \mathrm{M}, 900 \mu \mathrm{M}$ and $800 \mu \mathrm{M}$ for fibroblast cells derived from young, middle and old age humans respectively, almost all cells were dead. The $\mathrm{IC}_{50}$ of $\mathrm{H}_{2} \mathrm{O}_{2}$ for fibroblast cells derived from young, middle and old age humans were found to be $700 \mu \mathrm{M}, 400 \mu \mathrm{M}$ and $100 \mu \mathrm{M}$ respectively. ${ }^{\text {a Denotes }} \mathrm{p}<0.05$ compared to $0 \mu \mathrm{M} \mathrm{H}_{2} \mathrm{O}_{2}$. Data is presented as means $\pm \operatorname{SD}(n=3)$

additional factors are likely to contribute to aging processes. Thus, it has been hypothesized that oxidative stress is a major determinant of human aging in vivo and that the resistance of animals to oxidative stress may decrease with advancing age. ${ }^{9,10}$ There is increasing evidence that this aspect of the aging process can be reproduced in vitro. For example, it has been shown that increasing the concentration of reactive oxygen species (ROS), either by increasing the oxygen partial pressure, or by treating cells with $\mathrm{H}_{2} \mathrm{O}_{2}$, can induce premature senescence in young diploid human fibroblasts. ${ }^{11} \mathrm{H}_{2} \mathrm{O}_{2}$ is one of the oxidant species and it can be genotoxic. Treatment of human fibroblast with $\mathrm{H}_{2} \mathrm{O}_{2}$ which induced oxidative damage results in a growth arrest state that is similar to senescence cell. ${ }^{12}$

If free radicals and oxidative stress are at least partly responsible for lifespan and aging, it follows that antioxidant should prolong life and retard aging. The biological activity of vitamin $\mathrm{E}$ has generally been associated with it well-defined antioxidant property. Vitamin E is the major chain-breaking antioxidant preventing the propagation of oxidative stress, especially in biological membranes. ${ }^{13}$ Vitamin E also has revealed many important molecular properties, such as the scavenging of ROS to prevent oxidative damage that is associated with many diseases, or the modulation of signal transduction and gene expression in antioxidant and non-antioxidant manners. ${ }^{14}$ The other biological functions of vitamin $\mathrm{E}$ that are unrelated to its antioxidant properties include its roles in cellular signalling, gene expression, immune response, and apoptosis are now considered to be of importance. ${ }^{15,16}$ In the vitamin E group, $\alpha$-tocopherol is considered to be the most active form. However, recently, tocotrienol have gained increasing scientific interest due to their eminent antioxidant effects and a nonantioxidant activity profile that differs somewhat from that of tocopherol. ${ }^{13}$ Tocotrienols are identi$\mathrm{cal}$ in structure to tocopherols except for the degree of saturation in their side chain. Tocopherol has a saturated phytyl tail, while tocotrienols posses an unsaturated isoprenoid side chain. The prenyl side chain of tocotrienol has been postulated to be responsible for the differential membrane distribution and metabolism of tocotrienols when compared with tocopherols. $\alpha$-Tocotrienol was observed in vitro to possess a remarkably higher antioxidant activity against lipid peroxidation than $\alpha$-tocopherol. This was due to a more uniform distribution in the membrane lipid bilayer providing a more efficient interaction of the chromanol ring with lipid radicals. ${ }^{17}$

In view of this, it is of interest to investigate the effects of tocotrienol in preventing oxidative stress-induced cellular aging by determining telomere lengths and telomerase activities in normal skin fibroblast derived from young, middle and old age humans. Therefore the objective of this study was to determine the protective effects of palm $\gamma$-tocotrienol treatment before or after $\mathrm{H}_{2} \mathrm{O}_{2}$-induced oxidative stress on cell viability, telomere length and telomerase activity in normal human skin fibroblast cell lines derived from different age groups viz; young (21-yearold), middle (40-year-old) and old (68-year-old).

\section{Results}

$\mathrm{IC}_{50}$ determination of $\mathrm{H}_{2} \mathrm{O}_{2}$ and $\gamma$-tocotrienol. Results showed that the number of viable cells was not significantly different from control after exposure to less than $500 \mu \mathrm{M}, 300 \mu \mathrm{M}$ and $200 \mu \mathrm{M}$ for fibroblast cells derived from young, middle and old age humans respectively (Fig. 1). However, exposure to $700 \mu \mathrm{M}, 400 \mu \mathrm{M}$ and $100 \mu \mathrm{M} \mathrm{H}_{2} \mathrm{O}_{2}$ reduced viable cell number by about $50 \%\left(\mathrm{IC}_{50}\right)$ for fibroblast cells derived from young, middle and old age humans respectively. Almost all the cells were not viable at $\mathrm{H}_{2} \mathrm{O}_{2}$ concentration of $1,000 \mu \mathrm{M}, 900 \mu \mathrm{M}$ and $800 \mu \mathrm{M}$ for fibroblast cells derived from young, middle and old age humans respectively. Incubation with $\gamma$-tocotrienol for 24 hours caused an increase in the number of viable cells (Fig. 2 ) with the highest cell viable at $\gamma$-tocotrienol concentration of $80 \mu \mathrm{M}$ for YF and $40 \mu \mathrm{M}$ for fibroblast cells derived from middle and old age humans (optimum dose). However incubation with $200 \mu \mathrm{M}, 300 \mu \mathrm{M}$ and $100 \mu \mathrm{M} \gamma$-tocotrienol reduced viable cell number by about $50 \%\left(\mathrm{IC}_{50}\right)$ for fibroblast cells derived from young, middle and old age humans respectively. Almost all the cells were not viable at $\gamma$-tocotrienol concentration of $500 \mu \mathrm{M}$ for fibroblast cells derived from young and middle age humans and $150 \mu \mathrm{M}$ for fibroblast cells derived from old age human.

Morphological changes with $\mathrm{H}_{2} \mathrm{O}_{2}$ and $\gamma$-tocotrienol treatment. Control fibroblasts derived from different age humans have live cells that were stained green with Calcein-AM whereas fibroblasts exposed to $\mathrm{IC}_{50} \mathrm{H}_{2} \mathrm{O}_{2}$ underwent apoptosis and were stained red with propidium iodide (Fig. 3). Fibroblasts derived from young age human showed normal spindle cells with round uniform nuclei and elongated cytoplasm (Fig. 3Ai), while young fibroblasts which were exposed to $\mathrm{H}_{2} \mathrm{O}_{2}$ showed pyknotic nuclei 
with shrunken cytoplasm (Fig. 3Aii). Normal looking fibroblasts but more compact with increased cellularity were observed with $\gamma$-tocotrienol treatment (Fig. 3Aiii). Fibroblasts derived from middle age human showed normal nuclei, their cytoplasms were spindled but shorter than young fibroblasts (Fig. 3Bi). Middle age fibroblasts which were exposed to $\mathrm{H}_{2} \mathrm{O}_{2}$ showed pyknotic nuclei with smudged and elongated cytoplasm (Fig. 3Bii). Fibroblasts treated with $\gamma$-tocotrienol however showed similar morphology to untreated control fibroblasts but the cells were more compact (Fig. 3Biii). Old fibroblasts showed mild variations in nuclear size with spindled cytoplasm (Fig. 3Ci) while fibroblasts exposed to $\mathrm{H}_{2} \mathrm{O}_{2}$ showed pleomorphic nuclei and some pyknotic nuclei, their cytoplasms were thin, elongated and string-like (Fig. 3Cii). Treatment with $\gamma$-tocotrienol resulted in similar morphology of old fibroblasts to young fibroblasts (Fig. 3Ciii).

Effect of $\gamma$-tocotrienol on $\mathrm{H}_{2} \mathrm{O}_{2}$-induced oxidative stress. Treatment of fibroblasts with $\mathrm{IC}_{50}$ dose of $\mathrm{H}_{2} \mathrm{O}_{2}$ resulted in $50 \%$ reduction in cell viability (Fig. 4). Pretreatment with optimum concentration of $\gamma$-tocotrienol protected fibroblast cells derived from all age groups against $\mathrm{H}_{2} \mathrm{O}_{2}$-induced cell loss significantly $(\mathrm{p}<0.05)$. The protective effects of $\gamma$-tocotrienol was observed much higher in fibroblast cells derived from middle and old age humans compared to fibroblast cells derived from young age human. This protection however was not seen in cells pretreated with high dose $\left(\mathrm{IC}_{50}\right.$ dose) of $\gamma$-tocotrienol. Treatment of $\gamma$-tocotrienol after exposure to $\mathrm{H}_{2} \mathrm{O}_{2}$-induced oxidative stress was also found to increase the number of cell viable in fibroblasts derived from all age groups. The optimum dose of $\gamma$-tocotrienol decreased the number of $\mathrm{H}_{2} \mathrm{O}_{2}$-induced cell loss significantly ( $\mathrm{p}$ $<0.05$ ). This protective effects was almost similar to the effect of $\gamma$-tocotrienol treatment before the cells were exposed to $\mathrm{H}_{2} \mathrm{O}_{2}$. However high concentration of $\gamma$-tocotrienol $\left(\mathrm{IC}_{50}\right.$ dose) did not provide significant protection against $\mathrm{H}_{2} \mathrm{O}_{2}$-induced cell loss in fibroblast cells derived from all age groups.

Estimation of telomere length. Figure 5 shows the Southern blot analysis of fibroblast cells with different treatments. In fibroblast cells derived from old age human, the telomere length is shorter compared to fibroblast cells derived from young age human (Fig. 6). Treatment of fibroblast cells with $\mathrm{IC}_{50}$ dose of $\mathrm{H}_{2} \mathrm{O}_{2}$ resulted in shortening of telomere length. Pretreatment with optimum and $\mathrm{IC}_{50}$ doses of $\gamma$-tocotrienol protected against $\mathrm{H}_{2} \mathrm{O}_{2}$ induced telomere shortening significantly $(\mathrm{p}<0.05)$ in fibroblast cells derived from young and old age humans. Treatment of $\gamma$-tocotrienol after exposure to $\mathrm{H}_{2} \mathrm{O}_{2}$-induced oxidative stress was also found to protect against $\mathrm{H}_{2} \mathrm{O}_{2}$-induced telomere shortening significantly $(\mathrm{p}<0.05)$ in fibroblast cells derived from young and old age humans.

Estimation of telomerase activity. Figure 7 shows the representative PCR analysis for telomerase activity of fibroblast cells with different treatments. The effects of $\gamma$-tocotrienol on telomerase activity is shown in Figure 8. Results showed that telomerase activity is higher in fibroblast cells derived from young age human compared to fibroblast cells derived from middle and old age humans. Treatment of fibroblast cells with $\mathrm{IC}_{50}$ dose of $\mathrm{H}_{2} \mathrm{O}_{2}$ resulted in reduction of telomerase activity. Pretreatment with optimum dose of $\gamma$-tocotrienol protected against $\mathrm{H}_{2} \mathrm{O}_{2}$-induced

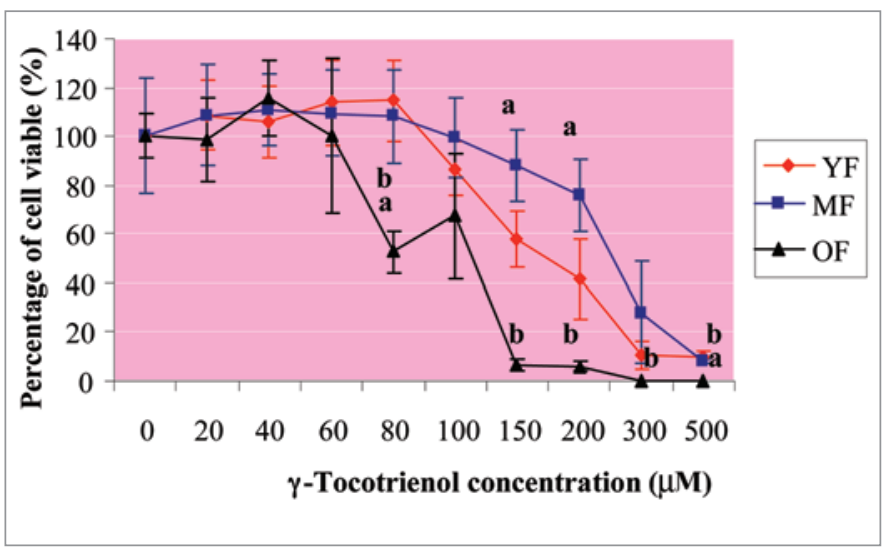

Figure 2. Cytotoxic effects of $\gamma$-tocotrienol on fibroblast cell lines as assessed by MTS assay. Percent MTS reduction corresponds to the viable cell number. Fibroblasts were incubated with increasing concentrations of $\gamma$-tocotrienol for 24 hours at $37^{\circ} \mathrm{C}$. Incubation with $\gamma$-tocotrienol caused a significant increase in the number of cell viable. The percentage of the viable cell is highest at $\gamma$-tocotrienol concentration of $80 \mu \mathrm{M}$ for fibroblast cells derived from young (YF) age human and $40 \mu \mathrm{M}$ for fibroblast cells derived from middle (MF) and old (OF) age humans. Cell viability decreased by $50 \%\left(\mathrm{IC}_{50}\right)$ with $\gamma$-tocotrienol incubation at $230 \mu \mathrm{M}, 280 \mu \mathrm{M}$ and $110 \mu \mathrm{M}$ for fibroblast cells derived from young, middle and old age humans respectively. Almost all cells were dead at $\gamma$-tocotrienol more than $500 \mu \mathrm{M}$ for fibroblast cells derived from young and middle age humans and $150 \mu \mathrm{M}$ for fibroblast cells derived from old age human. ${ }^{a}$ Denotes $p<0.05$ compared to fibroblast cells derived from young age human, ${ }^{b} \mathrm{p}<0.05$ compared to fibroblast cells derived from middle age human. Data is presented as means $\pm S D$, $\mathrm{n}=3$.

telomerase activity loss significantly $(\mathrm{p}<0.05)$ in fibroblast cells derived from all age groups. However high concentration of $\gamma$-tocotrienol $\left(\mathrm{IC}_{50}\right.$ dose $)$ and treatment of $\gamma$-tocotrienol after exposure to $\mathrm{H}_{2} \mathrm{O}_{2}$-induced oxidative stress did not provide significant protection against $\mathrm{H}_{2} \mathrm{O}_{2}$-induced telomerase activity loss in fibroblast cells derived from all age groups.

\section{Discussion}

Accumulation of oxidative damage plays an important role in aging and associated diseases. ${ }^{18}$ The pioneering discovery of Hayflick and Moorhead identified the cultured human diploid fibroblast (HDF) as a potential model for aging. ${ }^{1}$ There is evidence that in vitro cellular senescence may directly correlate with aging in vivo. In this study, we explored the effect of $\mathrm{H}_{2} \mathrm{O}_{2}$ on fibroblast cell lines derived from young, middle and old age humans and determined the protective effect of $\gamma$-tocotrienol against $\mathrm{H}_{2} \mathrm{O}_{2}$-induced oxidative stress by determining cell viability as measured by the MTS assay, and examining the morphology of cells by staining with specific fluorescence dyes that differentiate live from apoptotic cells, determination of telomere length as well as telomerase activity using Southern blot analysis and telomere repeat amplification protocol respectively.

The data showed that $\mathrm{H}_{2} \mathrm{O}_{2}$ at concentrations $700 \mu \mathrm{M}, 400$ $\mu \mathrm{M}$ and $100 \mu \mathrm{M}$ were cytotoxic to fibroblast cells derived from 


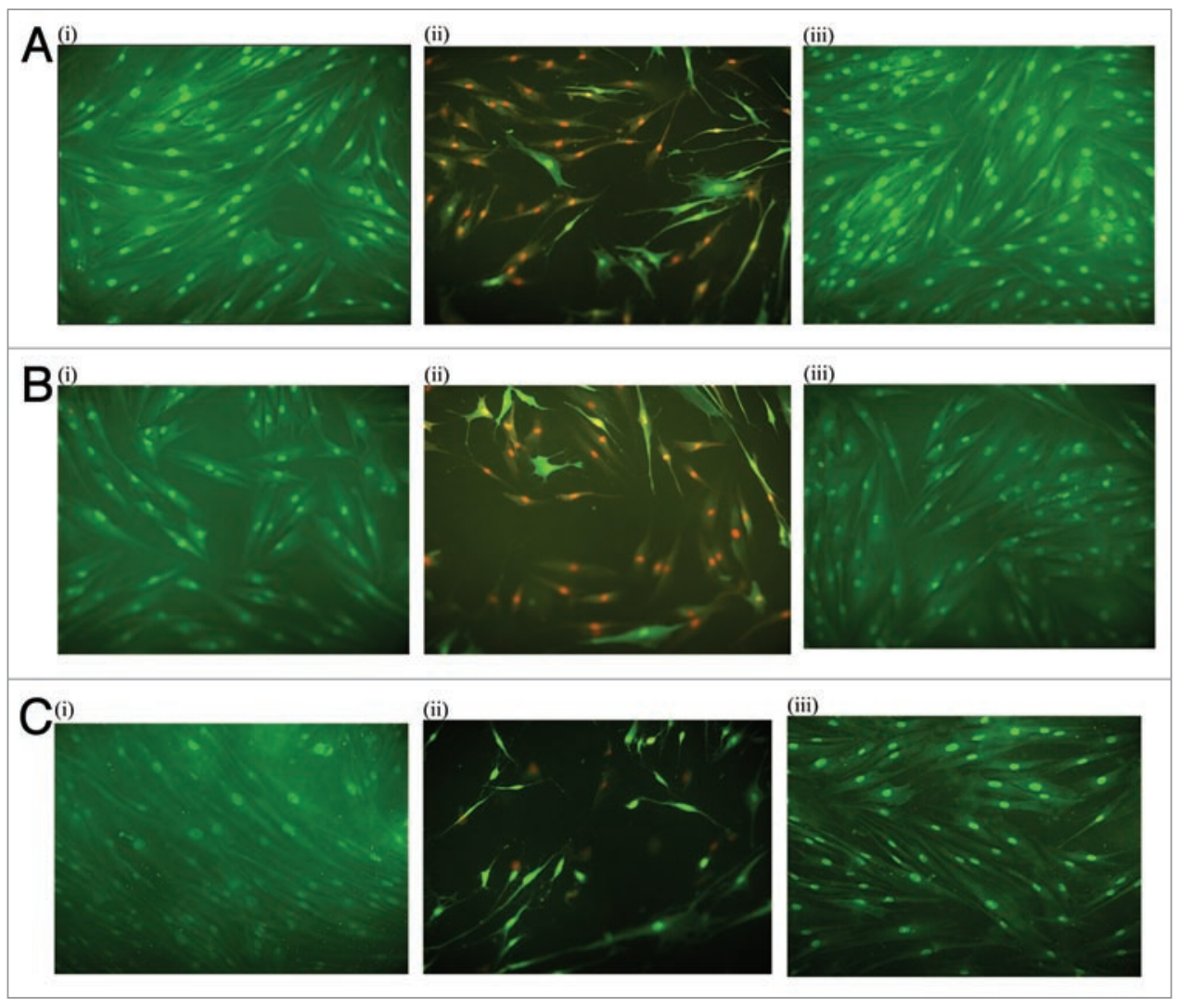

Figure 3. Fluorescence cell death staining for fibroblast cell lines derived from young (A), middle (B) and old (C) age humans, for untreated control fibroblasts (i), fibroblasts exposed to $\mathrm{H}_{2} \mathrm{O}_{2}$ (ii) at $700 \mathrm{M}, 400 \mathrm{M}$ and $100 \mathrm{M}$ for 2 hours respectively and fibroblasts treated with -tocotrienol (iii). Live cells were stained with $30 \mathrm{M}$ Calcein-AM (green) and dead cells were stained with 7.5 M propidium iodide ( $\mathrm{PI}$, red). Micrographs are shown at $\mathrm{X} 40$ magnification.

young, middle and old age humans respectively as it increased the number of cell loss as well as the number of apoptotic cells as shown by the fluorescence dyes staining. Almost all the cells were not viable at $\mathrm{H}_{2} \mathrm{O}_{2}$ concentration of $1000 \mu \mathrm{M}$, $900 \mu \mathrm{M}$ and $800 \mu \mathrm{M}$ for fibroblast cells derived from young, middle and old age humans respectively. This is in agreement with earlier observations. ${ }^{19} \mathrm{H}_{2} \mathrm{O}_{2}$ has been reported to directly stimulate endonuclease activity in renal tubular epithelial cells, leading to DNA fragmentation and cell death via apoptosis. ${ }^{20}$ The present data showed that fibroblast cells derived from old age human was more susceptible to the action of $\mathrm{H}_{2} \mathrm{O}_{2}$. This is in agreement with earlier observations. ${ }^{21} \mathrm{Old}$ fibroblasts were reported to be more sensitive to oxidative stress due to decreased antioxidant activity, less capability to repair, increased reactive oxygen species (ROS) production, and increased sensitivity of DNA towards the action of ROS. ${ }^{22}$

The data showed that at low concentration, $\gamma$-tocotrienol increased the number of viable cell. At $\gamma$-tocotrienol concentration of $80 \mu \mathrm{M}$ the number of cell viable is maximum for young fibroblasts and $40 \mu \mathrm{M}$ for middle and old fibroblasts. However, high concentration of $\gamma$-tocotrienol is cytotoxic. There was more than $50 \%$ reduction in viable cell number at concentrations greater than $230 \mu \mathrm{M}, 280 \mu \mathrm{M}$ and $110 \mu \mathrm{M} \gamma$-tocotrienol for young, middle and old fibroblasts respectively. This probably reflects the pro-oxidant activity of $\gamma$-tocotrienol.

The present data also showed that $\gamma$-tocotrienol provides protection against $\mathrm{H}_{2} \mathrm{O}_{2}$-induced cell loss in fibroblast cells derived from all age groups. The protection was more effective in middle and old fibroblasts. Previous study reported that vitamin E reduced $\mathrm{H}_{2} \mathrm{O}_{2}$-induced $\mathrm{HO}^{*}$ generation and subsequent DNA base pair modification in human oral epithelial cells. ${ }^{23}$ Vitamin $\mathrm{E}$ was found to decrease $\mathrm{H}_{2} \mathrm{O}_{2}$-induced DNA strand breaks in human skin cell line VH10. ${ }^{24}$ Konopacka et al. (1998) reported that the addition of vitamin E immediately after radiation treatment to bone marrow polychromatic erythrocytes, reduced radiation-induced micronucleus formation. ${ }^{25}$ It has been suggested that the inhibitory effect of vitamin E micronucleus formation may be due to modulation of the DNA repair system. Indeed, measurement of DNA repair ability tested in lymphocytes indicated that vitamin $\mathrm{E}$ increased the removal rate of damaged DNA compared to cells that are not treated with vitamin $\mathrm{E}$.

Telomere shortening is one of a few mechanisms mediating the development of the senescent phenotype. Telomere effects have been reported to be the predominat trigger of premature senescence in Werner syndrome, a disease that caused many clinical features associated with aging in human. Microarray analyses showed that mRNA expression patterns induced in senescent 
Werner syndrome cells appeared similar to those in normal strains. ${ }^{26}$

Data in the present study seems to suggest that both telomere shortening and decrease telomerase activity to be contributing factors in cellular aging. In the present study, treatment of fibroblast cells with $\mathrm{H}_{2} \mathrm{O}_{2}$ resulted in shortening of telomere length and reduction of telomerase activity. However, $\gamma$-tocotrienol treatment protected against $\mathrm{H}_{2} \mathrm{O}_{2}$-induced telomere shortening. $\gamma$-tocotrienol was also shown to protect against $\mathrm{H}_{2} \mathrm{O}_{2}$ induced telomerase activity loss in fibroblast cells derived from all age groups. Therefore the anti aging effect of tocotrienols may not only be due to their potent antioxidant properties but may also involve its role in maintaining telomere length possible mediated by telomerase. Consistent with the telomere theory of aging, telomerase positive human diploid fibroblasts were resistant to replicative senescence. 5 Our findings showed similar results whereby increased telomerase activity induced by $\gamma$-tocotrienol cause a significantly increased of telomere length in skin fibroblast derived from young and old age humans.

Our data that showed shortening of telomere length with $\mathrm{H}_{2} \mathrm{O}_{2}$ treatment is consistent with previous findings which reported that telomeres are particularly sensitive to oxidative stress. ${ }^{27} \mathrm{~A}$ study by Rubio et al. (2004) showed that telomerase influences the stress response indirectly by altering telomere length, mainly by elongating shorter telomeres. ${ }^{28}$ Thus, telomere length does not only determine replicative senescence, but also influences the senescence response to genotoxic agents.

Telomere shortening has been proven to be a cell division counter in proliferating fibroblast, or 'replicometer'. Telomere shortening down to a threshold length seems to be the best known predictor of senescence. ${ }^{29}$ A study by Von Zglinicki (2002) showed that telomere shortening is largely dependent on the interplay of oxidative stress and antioxidant defense rather than to counter clock of numbers of cell divisions. ${ }^{27} \mathrm{H}_{2} \mathrm{O}_{2}$ has been the most commonly used inducer of stress-induced premature senescence (SIPS), which shares features of replicative senescence including similar morphology, increase senescenceassociated $\beta$-galactosidase activity and cell cycle regulation. ${ }^{12}$ It has been reported that treating cells exogenously with a certain hydrogen peroxide $\left(\mathrm{H}_{2} \mathrm{O}_{2}\right)$ concentration can trigger entry into a senescent-like state. ${ }^{30}$ Sublethal dose $\left(\mathrm{IC}_{50}\right)$ of $\mathrm{H}_{2} \mathrm{O}_{2}$ used in this study induced shortening of telomere length and reduction in telomerase activity of skin fibroblast cells derived from young and old age humans.
Our data that showed $\gamma$-tocotrienol protected against $\mathrm{H}_{2} \mathrm{O}_{2}$ induced telomere shortening and protected skin fibroblast against $\mathrm{H}_{2} \mathrm{O}_{2}$-induced telomerase activity loss suggesting its effect in protecting and recovering the skin fibroblast from oxidative stress. Tocotrienols are capable of scavenging and quenching reactive oxygen species. This antioxidant activity however, remains mainly with its 'chain-breaking' property which neutralizes peroxyl and alkoxyl radicals generated during lipid peroxidation. ${ }^{13}$ As vitamin $\mathrm{E}$ is also involved in cell signaling, we suggested that elongation of telomere length and activation of telomerase activity by $\gamma$-tocotrienol may be mediated by cell signaling pathway. Previous study showed that vitamin E supplementation inhibits chromosomal alterations that are measured by chromosome gaps and breaks in c-myc proto-oncogene and transforming growth factor co-overexpressing transgenic mice. ${ }^{31}$ Additional studies have shown that c-myc may also be a 'key switch' for the induction of telomerase activity. ${ }^{32}$ The c-fos expression is induced when cells are exposed to $\mathrm{H}_{2} \mathrm{O}_{2}$ and $\mathrm{UV}$, and both $\mathrm{H}_{2} \mathrm{O}_{2}$ and $\mathrm{UV}$ induce DNA damage. ${ }^{33}$ The $\mathrm{c}-$ fos encodes a nuclear protein that forms heterodimer with jun and binds a common DNA site (AP-1) to regulate various transcriptional activity. Vitamin $\mathrm{E}$ treatment also has been shown to induce c-jun expression as well as AP-1 binding activity in human breast cancer cells. ${ }^{34,35}$ These studies suggest that the protective role of vitamin E against DNA damage induced by $\mathrm{H}_{2} \mathrm{O}_{2}$ and $\mathrm{UV}$ is in part, mediated by upregulation of c-fos expression and AP-1 binding activity. Hadshiew et al. (2000) in their study showed that there are homologies between certain protein kinases and telomeric protein suggest a link between 


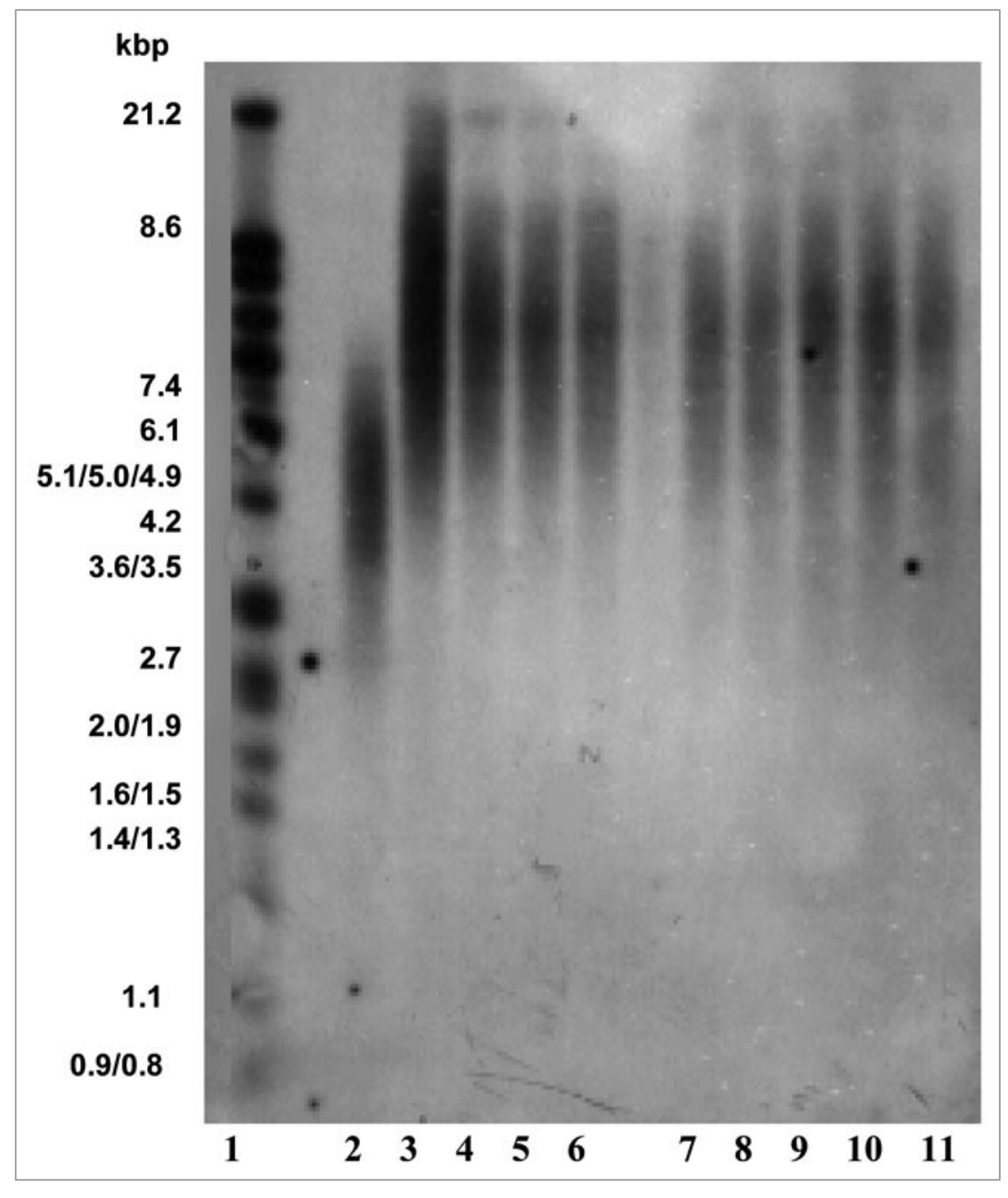

Figure 5. Representative Southern blot for fibroblast cell lines with different treatments. Telomeric DNA shows wide smears in all lanes. Lane I; molecular weight marker, lanes 2 and 3; control DNA low and high, lane 4; cells without any treatment, lane 5; cells treated with optimum dose of $\gamma$-tocotrienol, lane 6; cells treated with IC I $_{50}$ dose of $\gamma$-tocotrienol, lane 7; cells with $\mathrm{H}_{2} \mathrm{O}_{2}$-induced oxidative stress, lane 8; cells treated with optimum dos of $\gamma$-tocotrienol prior to $\mathrm{H}_{2} \mathrm{O}_{2}$ exposure, lane 9; cells treated with $\mathrm{IC}_{50}$ dose of $\gamma$-tocotrienol prior to $\mathrm{H}_{2} \mathrm{O}_{2}$ exposure, lane 10; cells treated with optimum dose of $\gamma$-tocotrienol after $\mathrm{H}_{2} \mathrm{O}_{2}$ exposure, lane II; cells treated with $\mathrm{IC}_{50}$ dose of $\gamma$-tocotrienol after $\mathrm{H}_{2} \mathrm{O}_{2}$ exposure. chromosome stability and cell cycle regulation. ${ }^{36}$ In fact, a critical reduction in telomere length appears to interfere with transcription of subtelomeric genes and leads to cell cycle arrest or apoptosis and finally the aging phenotype.

\section{Materials and Methods}

Materials. $\gamma$-tocotrienol extracted from palm oil, was supplied by the Malaysian Palm Oil Board. Eagle's Minimun Essential Medium (EMEM) and Iscove's Modified Dulbecco's Medium (IMDM) were purchased from Flowlab, (Australia) which also provided trypsin, trypan blue, L-glutamin, antibiotics, sodium pyruvate and non-essential amino acids. Fetal calf serum (FCS) from PAA (PAA lab, Austria). $\mathrm{H}_{2} \mathrm{O}_{2}$ was purchased from BDH (British Drug House). Telomere Length Assay kit was purchased from Roche, Germany while TRAPeze Telomerase Detection kit was purchased from Chemicon, USA. Wizard Genomic Purification Kit was obtained from Promega, USA. Other chemicals and solvents were supplied by Sigma or Merck (Darmstadt, Germany). Fibroblast cells were obtained from American Tissue Culture Collection.

Cell culture and treatment protocols. Normal skin fibroblast cell lines derived from young (21-year-old, YF) and middle age (40-year-old, MF) humans were established in complete culture media (CCM) which contains Iscoves Modified Dulbeccos Media (IMDM) (Flowlab, Australia) containing $3.7 \mathrm{~g} \mathrm{NaHCO}$ supplemented with L-glutamin, $100 \mathrm{unit} / \mathrm{ml}$ penicillin, $100 \mu \mathrm{g} / \mathrm{ml}$ streptomycin, amphostat $0.25 \mu \mathrm{g} / \mathrm{ml}$ and $10 \%$ fetal calf serum (FCS). Cells were maintained at in a humidified atmosphere of $5 \% \mathrm{CO}_{2}$ at $37^{\circ} \mathrm{C}$. Normal skin fibroblast cell lines derived from old age human (68-year-old, OF) were

\begin{abstract}
Figure 6. Effect of $\gamma$-tocotrienol on telomere length (TRF length) of human skin fibroblast cell lines derived from different age groups. Cells were treated with optimum dose and $\mathrm{IC}_{50}$ dose of $\gamma$-tocotrienol prior or after $\mathrm{H}_{2} \mathrm{O}_{2}$ exposure. Protective effects of $\gamma$-tocotrienol against $\mathrm{H}_{2} \mathrm{O}_{2}$-induced telomere shortening was observed in fibroblast cells derived from young (YF) and old (OF) age humans. ${ }^{\text {DD }}$ enotes $p<0.05$ compared to fibroblast cells derived from young age human, ${ }^{b} \mathrm{p}<0.05$ compared to fibroblast cells derived from middle age human, ${ }^{c} p<0.05$ compared to control, ${ }^{\mathrm{d}} \mathrm{p}<0.05$ compared to $\mathrm{H}_{2} \mathrm{O}_{2}$-treated cells. Data is presented as means $\pm S D, n=3$.
\end{abstract}

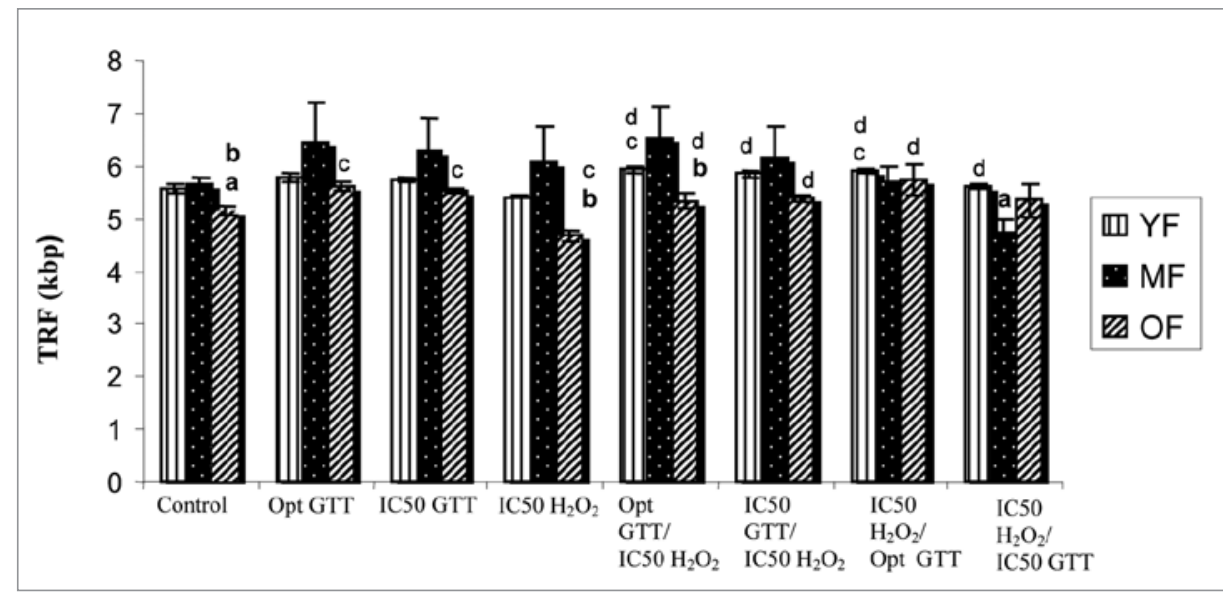


established in CCM which contains Eagle's Minimun Essential Medium (EMEM) (Flowlab, Australia) containing $3.7 \mathrm{~g} \mathrm{NaHCO}_{3}$ and Hepes supplemented with L-glutamin, $0.1 \mathrm{mM}$ non-essential amino acids, $1.0 \mathrm{mM}$ sodium pyruvate, 100 unit/ $\mathrm{ml}$ penicillin, $100 \mu \mathrm{g} / \mathrm{ml}$ streptomycin, amphostat $0.25 \mu \mathrm{g} / \mathrm{ml}$ and $10 \%$ FCS. The medium was equilibrated with a humidified atmosphere of $5 \% \mathrm{CO}_{2}$ at $37^{\circ} \mathrm{C}$. Cells were subcultured by passaging them at a ratio of $1: 3$ in regular intervals. Cells were passaged such that the monolayers never exceeded 70-80\% confluency. Cells at passage 6 (population doubling less than 12) were used for further analysis.

Analysis of cytotoxicity. $\gamma$-Tocotrienol was incubated in FCS overnight at $37^{\circ} \mathrm{C}$. Dilutions of $\mathrm{H}_{2} \mathrm{O}_{2}$ and $\gamma$-tocotrienol in IMDM or EMEM were made fresh just prior to each experiment. Small volumes of $\mathrm{H}_{2} \mathrm{O}_{2}$ and $\gamma$-tocotrienol were added to each well to make final dilutions of $10-1,000 \mu \mathrm{M}$ of $\mathrm{H}_{2} \mathrm{O}_{2}$ and 20-200 $\mu \mathrm{M}$ of $\gamma$-tocotrienol, respectively. The cells were then agitated lightly. Cultures were incubated in a humidified incubator at $37^{\circ} \mathrm{C}$, $5 \% \mathrm{CO}_{2}$ with $\mathrm{H}_{2} \mathrm{O}_{2}$ for 2 hours and with $\gamma$-tocotrienol for 24 hours. Cell viability was assessed.

Analysis of cell viability. Cell viability was assessed with CellTiter 96* Aqueous NonRadioactive Cell Proliferation Assay (MTS, Promega, USA). The MTS employs 3-(4,5-dimethylthiazol2-yl)-5-carboxymethoxy phenyl 2-(4-sulfophenyl)-2H-tetrazolium (MTS) and the electron coupling agent phenazine methosulphate (PMS). The MTS compound is reduced by the dehydrogenase enzymes found in metabolically active cells into a formazan product that is soluble in the medium. The amount of colored formazan product is proportional to the number of viable cells. Briefly, $20 \mu \mathrm{l}$ MTS solution was added to each well and incubated in humidified incubator at $37^{\circ} \mathrm{C}$ in $5 \% \mathrm{CO}_{2}$ for $2-4$ hours. The quantity of formazan product present was determined by measuring the absorbance at $490 \mathrm{~nm}$ with a microtiter plate reader (VeraMax Molecular Devices, USA). Cell death staining make use of the fact that live cells have intracellular esterase that convert non-fluorescent cell-permeable calcein-AM to the intensely fluorescent calcein which is retained within the cells. Viable cell membranes are impermeable to propidium iodide. Dead cells however, allow propidium iodide to enter and bind to nucleic acid. Thus live cells stained with calcein-AM while dead and apoptotic cells stained with propidium iodide to give green and red fluorescence, respectively. Thirty $\mu \mathrm{g} / \mathrm{ml}$ calcein-AM and $7.5 \mu \mathrm{g} / \mathrm{ml}$ propidium iodide were added to cultured fibroblasts in chamber slides and incubated for 30 min. Thereafter, cultures were washed with PBS, fixed with fresh $2 \%$ paraformaldehyde and then coverslips mounted for microscopic examination. 
Analysis of protective effects of $\gamma$-tocotrienol. Cells were seeded at $2 \times 10^{6}$ cells $/ 10 \mathrm{ml}$ CCM in petri dish, then incubated with $\gamma$-tocotrienol for 24 hours (the concentration of $\gamma$-tocotrienol that caused maximum cell viability; optimum dose or the concentration of $\gamma$-tocotrienol that caused $50 \%$ cell viability; $\mathrm{IC}_{50}$ determined earlier) before or after the addition of $\mathrm{H}_{2} \mathrm{O}_{2}$ for 2 hours (the concentration of $\mathrm{H}_{2} \mathrm{O}_{2}$ that caused $50 \%$ cell viability; $\mathrm{IC}_{50}$ determined earlier). Cell viability, telomere length and telomerase activity were determined.

Estimation of telomere length. Genomic DNA was isolated using Wizard Genomic Purification Kit (Promega, USA). The DNA samples were processed separately for each treatment. Three $\mu \mathrm{g}$ of DNA was digested with 20 units each of HinfI and Rsa1 for 2 hours at $37^{\circ} \mathrm{C}$. Complete cutting is confirmed by electrophoresis of the DNA digests on $0.8 \%$ agarose gel. Fractionated DNA fragments were transferred to nylon membranes Hybond- $\mathrm{N}^{+}$ (Amersham, UK) by an alkaline transfer technique using capillary blotting. The blotted DNA fragments were hybridized to a digoxigenin (DIG)-labeled probe specific for telomeric repeats and incubated with a DIG-specific antibody covalently coupled to alkaline phosphatase. Finally, the immobilized telomere probe was visualized by virtue of alkaline phosphatase metabolizing CDP-Star, a highly sensitive chemiluminescence substrate. The average terminal restriction fragment (TRF) length was determined by comparing signals relative to a nuclear weight standard on X-ray film. The average TRF length of each sample could be obtained by scanning the exposed X-ray film and analyzed using ImageMaster Total lab software. TRF lenghts were recorded for simplicity as telomere lengths.

Estimation of telomerase activity. Detection of telomerase activity using the telomeric repeat amplification protocol (TRAP) in cultured cells involves the addition of TTAGGG repeats by telomerase to an oligonucleotide (TS), and the subsequent PCR amplification of these extension products with both the forward (TS) and reverse (CX) primers (Kim et al. 1994). The TRAPeze telomerase detection kit (Chemicon, USA) was used as recommended by the manufacturer with minor modifications. Briefly, cell pellets were stored at $-80^{\circ} \mathrm{C}$ until lysis was performed. The lysis buffer contained $1 \%$ Nonidet P-40 and $0.25 \mathrm{mM}$ sodium deoxycholate to increase the efficiency of extraction. Cells were lyzed,then left on ice for $30 \mathrm{~min}$, and centrifuged at $14,000 \mathrm{~g}$ for $20 \mathrm{~min}$ at $4^{\circ} \mathrm{C}$. The supernatant was flash-frozen and stored at $-80^{\circ} \mathrm{C}$. For the PCR reaction, $2 \mu \mathrm{l}$ of extract (corresponding to $100-1,000$ cells) was added to $48 \mu \mathrm{l}$ reaction mixture and two units of Taq DNA polymerase (Promega, USA). After incubation at room temperature for $30 \mathrm{~min}$ for the telomerase extension reaction, samples were heated to $92^{\circ} \mathrm{C}$ for $3 \mathrm{~min}$ to inactivate telomerase followed by PCR amplification. PCR products were electrophoresed on $10 \%$ polyacrylamide gel, and the gel was further analyzed and quantitated using the ImageMaster Total lab software. Telomerase activity was calculated as the ratio of the intensity of telomerase ladders to the intensity of the 36-bp internal standard.

Statistical data analysis. Each experiment was carried out in triplicates with at least three independent cultures with comparable results. Data are reported as mean \pm SD of at least three experiments. Comparison between groups were made by Student's t-test. $\mathrm{p}<0.05$ was considered statistically significant.

\section{Conclusion}

The results obtained showed that $\gamma$-tocotrienol at low concentration was able to protect against $\mathrm{H}_{2} \mathrm{O}_{2}$-induced cell loss in fibroblast cell lines derived from different age groups. $\gamma$-tocotrienol was also able to protect against $\mathrm{H}_{2} \mathrm{O}_{2}$-induced telomere shortening and telomerase activity loss. Therefore we suggest that $\gamma$-tocotrienol protects against oxidative stress-induced cellular aging by modulating the telomere length possibly via telomerase. However more studies need to be done in order to understand the mechanisms.

\section{Acknowledgements}

We thank Professor Dr. Hayati Abdul Rahman (Department of Pathology) and Associate Professor Dr. Azian Abdul Latif (Department of Anatomy) for their help in interpreting the morphological study. This research was supported by the Ministry of Science, Technology and Innovation under the Intensified Research in Prioritised Area (IRPA) grant 06-02-02-0021/ PR0008/09-7.

\section{References}

1. Hayflick L, Moorhead PS. The limited in vitro lifetime of human diploid cell strains. Exp Aging Research $1961 ; 25: 585-621$.

2. Kim S-H, Kaminker P, Campisi J. Telomeres, aging and cancer: in search of a happy ending. Oncogene 2002; 21:503-11.

3. Baird DM. Telomeres II. Exp Gerontol 2008; 43:159.

4. Kappei D, Londono-Vallejo A. Telomere length inheritance and aging. Mech Aging Dev 2008; 129:17-26.

5. Matuoka K, Chen KY. Telomerase positive human diploid fibroblasts are resistant to replicative senescence but not premature senescence induced by chemical reagents. Biogerontol 2002; 3:365-72.

6. Gupta N, Taneja R, Pandey A, Mukesh M, Singh H, Gupta SC. Replicative senescence, telomere shortening and cell proliferation rate in Gaddi goat's skin fibroblast cell line. Cell Biol Int 2007; 31:1257-64.
7. Proctor CJ, Kirkwood TB. Modelling cellular senescence as a result of telomere state. Aging Cell 2003; 2:151.

8. Passos JF, von Zglinicki T. Mitochondria, telomeres and cell senescence. Exp Gerontol 2005; 40:466-72.

9. Magalhaes JP, Chaininiaux F, Remacle J, Toussaint O. Stress-induced premature senescence in BJ and hTERTBJ1 human foreskin fibroblasts. FEBS Lett 2002; 523:157-62.

10. Weinert BT, Timiras PS. Physiology of Aging Invited review: Theories of aging. J Appl Physiol 2003; 95:1706-16.

11. Chen QM, Prowse KR, Tu VC, Purdom S, Linskens $\mathrm{MH}$. Uncoupling the senescent phenotype from telomere shortening in hydrogen peroxide-treated fibroblasts. Exp Cell Res 2001; 265:294-303.

12. Chen Q, Ames BN. Senescence-like growth arrest induced by hydrogen peroxide in human diploid fibroblast F65 cells. Proc Natl Acad Sci USA 1994; 91:4130-4
13. Sebastian S, Muller WE, Eckert GP. Tocotrienols: Constitutional Effects in Aging and Disease J. Nutr 2005; 135:151-4

14. Zingg JM. Modulation of signal transduction by vitamin E. Molecular Aspects of Medicine 2007; 28:481506

15. Azzi A, Ricciarelli R, Zingg JM. Non-antioxidan molecular functions of $\alpha$-tocopherol (vitamin E). FEBS Lett 2002; 519:8-10.

16. Brigelius-Flohe R, Kelly FJ, Salonen JT, Neuzil J, Zings JM, Azzi A. The European perspective on vitamin E: current knowledge and future research. Am J Clin Nutr 2002; 76:703-16.

17. Kamat JP, Sarma HD, Devasagayam TPA, Nesaretnam $\mathrm{K}$, Basiron Y. Tocotrienols from palm oil as effective inhibitors of protein oxidation and lipid peroxidation in rat liver microsomes. Mol Cell Biochem 1997; 170:131-8

18. Finkel T, Holbrook NJ. Oxidants, oxidative stress and biology of ageing. Nature 2000; 408:239-47. 
19. Chen QM, Bartholomew JC, Campisi J, Acosta M, Reagen JD, Ames BN. Molecular analysis of $\mathrm{H}_{2} \mathrm{O}_{2}$ induced senescent-like growth arrest in normal human fibroblast: $\mathrm{p} 53$ and $\mathrm{Rb}$ control $\mathrm{G}_{1}$ arrest but not cell replication. Biochem J 1998; 332:43-50.

20. Ueda N, Shah SY. Endonuclease-induced DNA damage and cell death in oxidant injury to renal tubular epithelial cells. J Clin Invest 1992; 90:2594-7.

21. Wolf IF, Torsello A, Covacci V, Fasanella S, Montanari M, Boninsegna A, Cittadini A. Oxidative DNA damage as a marker of aging in WI-38 human fibroblasts. Exp Gerontol 2002; 37:647-56.

22. Kaneko T, Tahara S, Taguchi T, Kondo H. Accumulation of oxidative damage, 8-oxo-2'-deoxyguanosine, and change of repair systems during in vitro cellular aging of cultured human skin fibroblasts. Mut Res 2001; 487:19-30.

23. Royack GA, Nguyen MP, Tong DC, Poot M, Oda D. Response of human oral epithelial cells to oxidative damage and the effect of vitamin E. Oral Oncol 2000; 36:37-41

24. Slamenova D, Horvathova E, Kosikova B, Ruzekova L, Labaj J. Detection of lignin biopolymer- and vitamin E-stimulated reduction of DNA strand breaks in $\mathrm{H}_{2} \mathrm{O}_{2}$ and MNNG-treated mammalian cells by the comet assay. Nutr Cancer 1999; 33:88-94.
25. Konopacka M, Widel M, Rzeszowska-Wolney J. Modifying effect of vitamin $\mathrm{C}, \mathrm{E}$ and beta-carotene against gamma-ray-induced DNA damage in mouse cells. Mut Res 1998; 417:85-94.

26. Choi D, Whittier PS, Ashima J, Oshima J, Funk WD. Telomerase expression prevents replicative senescence but does not fully reset mRNA expression patterns in Werner syndrome cell strains. Faseb J 2001; 15:101420.

27. von Zglinicki T. Oxidative stress shortens telomeres. Trends Biochem Sci 2002; 27:339-44.

28. Rubio MA, Davalos AR, Campisi J. Telomere length mediates the effects of telomerase on the cellular response to genotoxic stress. Exp Cell Research 2004; 298:17-27.

29. Hayflick L. The illusion of cell immortality. $\mathrm{Br}$ Cancer 2000; 83:841-6.

30. Lu T, Finkel T. Free radicals and senescence. Exp Cell Res 2008; 314:1918-22.

31. Factor VM, Laskowska D, Jensen MR, Woitach JT, Popescu NC, Thorgeirsson SS. Vitamin E reduces chromosomal damage and inhibits hepatic tumor formation in a transgenic mouse model. Proc Natl Acad Sci USA2000; 97:2196-201.
32. Dang C. c-Myc target genes involved in cell growth, apoptosis and metabolism. Mol Cell Biol 1999; 19:111.

33. Haas S, Kaina B. c-Fos is involved in the cellular defense against the genotoxic effect of UV radiation. Carcinogenesis 1995; 16:985-91.

34. Vollgraf U, Wegner M, Richter-Lansberg C. Activation of AP-1 and nuclear factor-kappaB transcription factors is involved in hydrogen peroxide-induced apoptotic cell death of oligodendrocytes. J Neurochem 1999; 73:2501-9.

35. Zhao B. Involvement of activator protein (AP-1) in induction of apoptosis by vitamin $\mathrm{E}$ succinate in human breast cancer cells. Mol Carcinogen 1997; 19:180-90.

36. Hadshiew IM. Skin aging and photoaging: The role of DNA damage and repair. Am J Contact Dermatitis 2000; 11:19-25. 


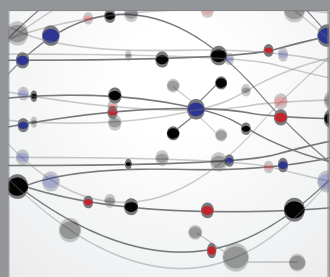

The Scientific World Journal
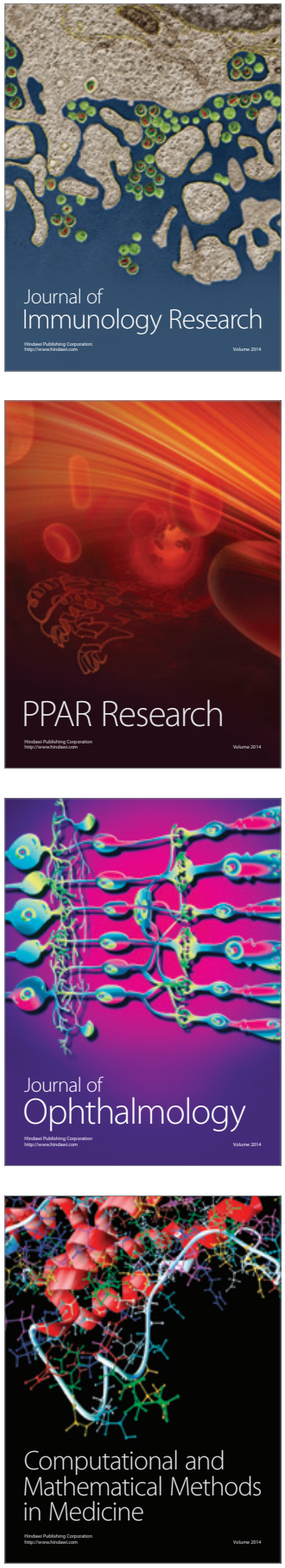

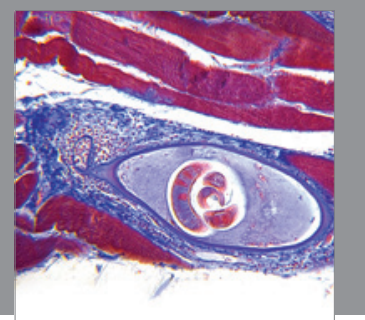

Gastroenterology

Research and Practice
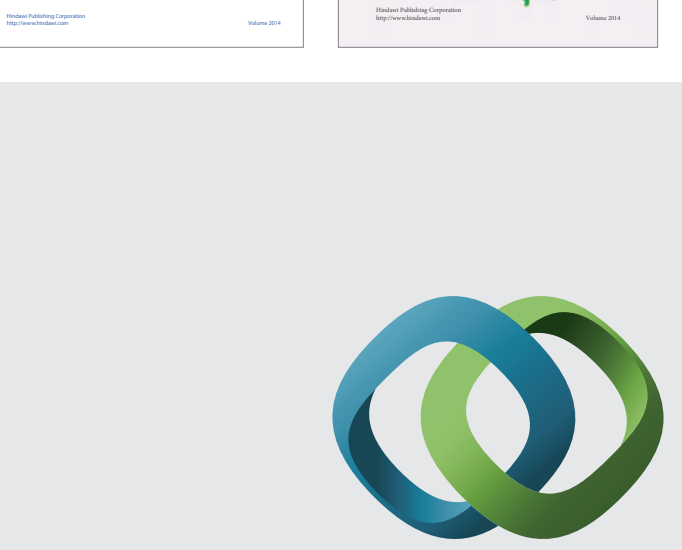

\section{Hindawi}

Submit your manuscripts at

http://www.hindawi.com
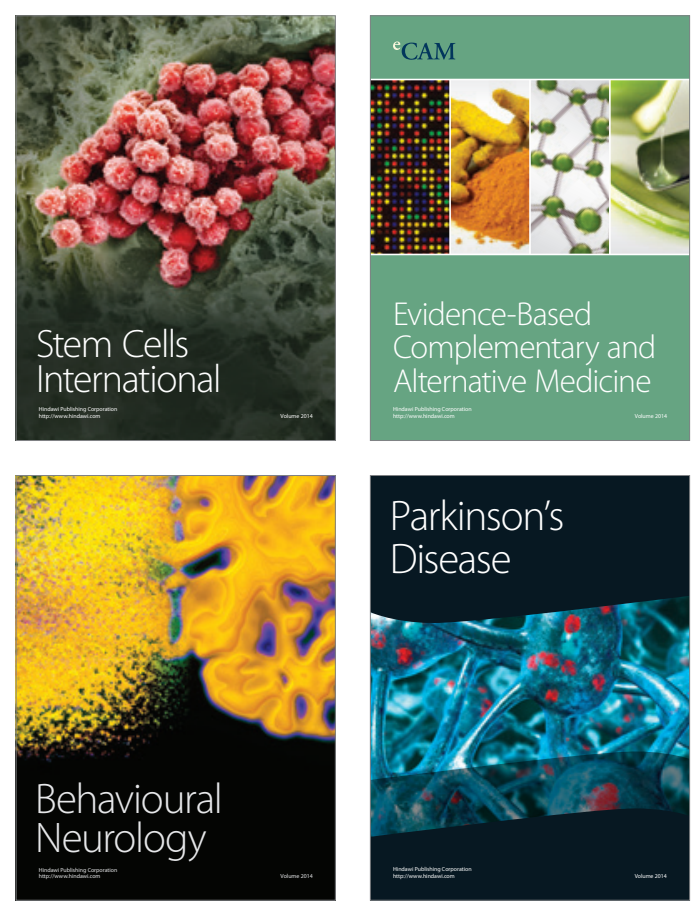

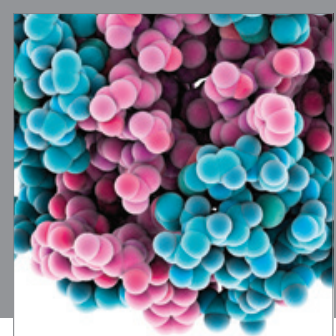

Journal of
Diabetes Research

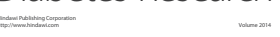

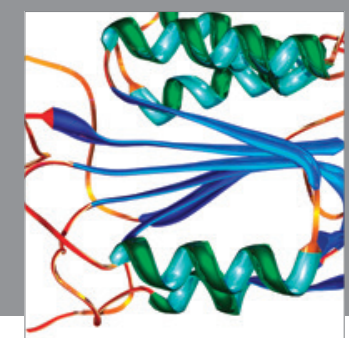

Disease Markers
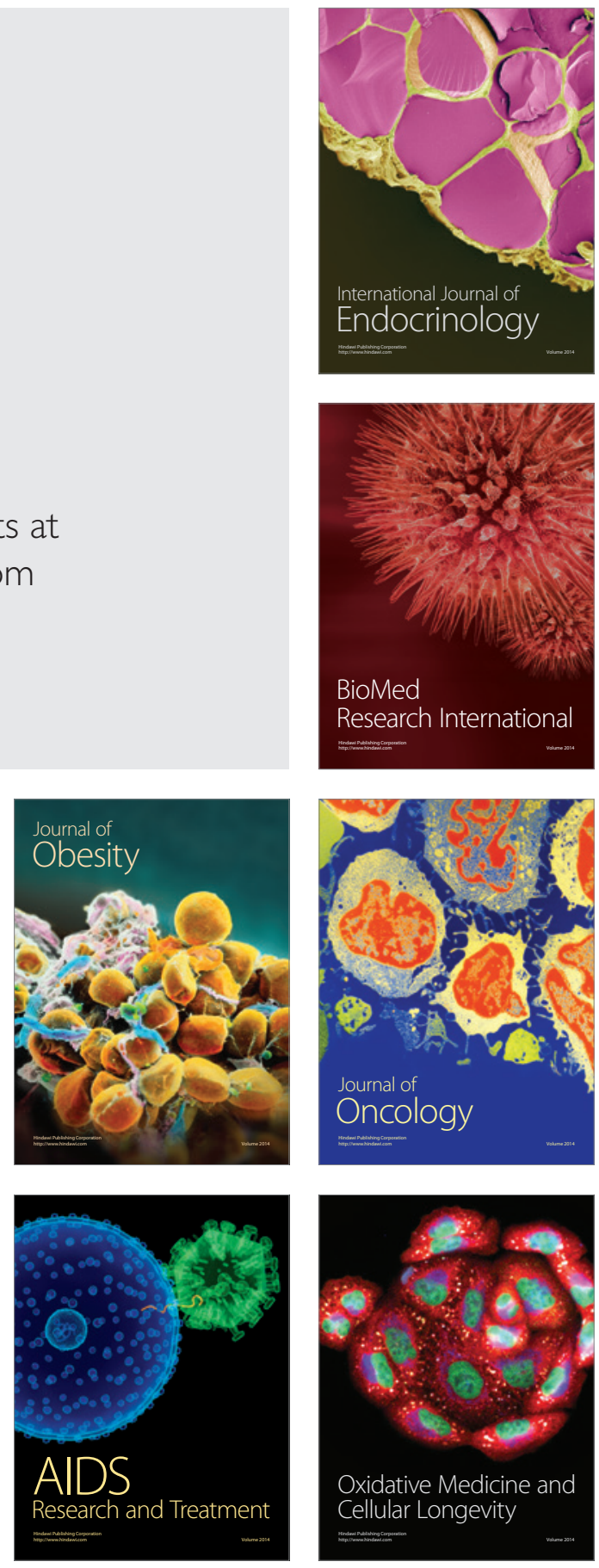